\title{
O Caminho das Tropas Desterro-Lages e o legado patrimonial: potencialidades para o desenvolvimento do seu turismo cultural
}

\author{
The Merchants' Road of Desterro-Lages and the heritage legacy: potentialities \\ for the development of its cultural tourism
}

\section{La Route des Marchands Desterro-Lages et l'héritage patrimonial: potentialités pour le développement de son tourisme culturel}

\author{
El Camino de los Comerciantes Desterro-Lages y el legado patrimonial: \\ potencialidades para el desarrollo de su turismo cultural
}

\author{
Jonei Bauer ${ }^{1}$ \\ Ana Paula Lisboa Sohn ${ }^{1}$ \\ Recebido em 01/08/2017; revisado e aprovado em 20/12/2017; aceito em 27/12/2017 \\ DOI: http://dx.doi.org/10.20435/inter.v19i3.1677
}

\begin{abstract}
Resumo: Diante da importância do patrimônio cultural como fator para se pensar o planejamento de um destino turístico, o objetivo deste artigo é levantar potencialidades de atrativos turísticos da primeira rota mercantilista entre as cidades catarinenses de Florianópolis e Lages. Para o alcance do objetivo, foi realizada uma pesquisa exploratória e analítica. Fez-se uma pesquisa bibliográfica e documental para o levantamento de informações específicas sobre o território, observando vestígios históricos e patrimônios culturais. A partir desta pesquisa, são identificadas potencialidades para o planejamento e desenvolvimento do turismo na região.
\end{abstract}

Palavras-chave: turismo cultural; planejamento do turismo; desenvolvimento local; Caminho das Tropas Desterro-Lages.

Abstract: The cultural heritage is an important factor in planning a tourist destination. The objective of this research is to observe the potential tourist attractions of the first mercantilist route between the brazilian cities of Florianópolis and Lages. To reach the objective, an exploratory and analytical research was carried out. A bibliographical and documentary research was done to evidence specific informations about the territory, observing historical vestiges and cultural patrimony. This research identified potentialities for the planning and development of tourism in the region.

Keywords: cultural tourism; tourism planning; local development; Merchants' Road of Desterro-Lages

Résumé: Le patrimoine culturel est un facteur important dans la planification d'une destination touristique. L'objectif de cette recherche est d'observer les attractions touristiques potentielles de la première route mercantiliste entre les villes brésiliennes de Florianópolis et Lages. Pour atteindre l'objectif, une recherche exploratoire et analytique a été réalisée. Une recherche bibliographique et documentaire a été faite pour prouver des informations spécifiques sur le territoire, en observant les vestiges historiques et le patrimoine culturel. Cette recherche a identifié des potentialités pour la planification et le développement du tourisme dans la région.

Mots-clés: tourisme culturel; planification du tourisme; développement local; La Route des Marchands Desterro-Lages.

Resumen: El patrimonio cultural es un factor importante en la planificación de un destino turístico. El objetivo de esta investigación es observar los atractivos turísticos potenciales de la primera ruta mercantilista entre las ciudades brasileñas de Florianópolis y Lages. Para alcanzar el objetivo se llevó a cabo un enfoque exploratório y analítico. Se realizó una investigación bibliográfica y documental para evidenciar informaciones específicas sobre el territorio, observando los vestigios históricos y el patrimonio cultural. Esta investigación identificó potencialidades para la planificación y desarrollo del turismo en la región.

Palabras clave: turismo cultural; planificación del turismo; desarrollo local; El Camino de los Comerciantes Desterro-Lages.

\footnotetext{
${ }^{1}$ Universidade do Vale do Itajaí (UNIVALI), Itajaí, Santa Catarina, Brasil.
} 


\section{INTRODUÇÃO}

A preservação dos vestígios históricos legados pelos antepassados tem o elo de servir como um suporte à memória de um passado já desaparecido ou despercebido nos dias atuais. A aceleração das atividades econômicas tem ameaçado paisagens culturais e naturais, muitas das quais em processo substitutivos, conformando espaços banalizados que perdem as referências peculiares do lugar (SANTOS, 1985). A região que abrange o traçado original do Caminho das Tropas Desterro-Lages vive sob essa tensão permanente entre o desenvolvimento das atividades econômicas e a preservação patrimonial. O processo de industrialização e urbanização, a promoção turística de outras culturas e o aumento das casas de segunda residência têm subvertido, sobremaneira, o sentido histórico da região.

Esta pesquisa tem por objetivo evidenciar possíveis atrativos turísticos do antigo Caminho das Tropas Desterro-Lages. Com foco no planejamento do turismo daquela região são apresentados elementos que compõem o patrimônio natural, histórico e cultural do denominado "Caminho das Tropas", a primeira rota mercantilista entre a antiga cidade de Desterro, atual Florianópolis, capital do Estado de Santa Catarina localizada no litoral, e a cidade de Lages, situada no planalto serrano catarinense.

Uma das justificativas que motivou esta pesquisa é a constatação da ausência de planejamento que explore as potencialidades turísticas do território que compreende o Caminho das Tropas em Santa Catarina. Constata-se que a regionalização do turismo em Santa Catarina não contemplou o fenômeno cultural do tropeirismo ${ }^{2}$ em suas regiões turísticas, perdendo oportunidades para explorar um fenômeno da cultura regional. Nesse sentido, salienta-se que o tropeirismo ainda hoje está ligado ao modus vivendi dos catarinenses, criando uma cultura diferenciada das demais.

Outra justificativa para a pesquisa é a relevância dos estudos sobre patrimônio cultural e planejamento turístico, amplamente pesquisado por Pinto-Correia (2001), Camargo (2002), Antonini (2003), Coriolano (2012; 2013), Carvalho e Fernandes (2012) e Hammerl e Silveira (2013).

\section{PESQUISA TEÓRICA}

O levantamento bibliográfico desta pesquisa está dividido em três eixos estruturantes, a saber: turismo cultural e patrimônio cultural, turismo e desenvolvimento local, e, planejamento do turismo no espaço rural. A escolha desses temas foi motivada pelas peculiaridades históricas, geográficas e sociais da região que abrange esta pesquisa, cujo foco intenta em evidenciar potencialidades para o planejamento e o desenvolvimento de um roteiro turístico para o antigo Caminho das Tropas Desterro-Lages.

\subsection{Turismo cultural e patrimônio: pensando o desenvolvimento}

O conceito de Turismo está intrinsicamente ligado à territorialidade, definida como o local específico onde ocorre o deslocamento de pessoas. Sendo assim, as acepções acerca do Turismo têm evoluído ao longo dos tempos, evidenciando que, desde os seus primórdios, seu

\footnotetext{
${ }^{2}$ Tropeirismo foi o movimento originado a partir das primeiras rotas mercantilistas pelos territórios correspondentes ao Sul e Sudeste do Brasil, além de territórios da Argentina, Paraguai e Uruguai. Os homens que realizavam esses trajetos eram denominados tropeiros, cuja atividade principal estava baseada na troca de mercadorias, principalmente, o gado (BRUM, 1999, p. 125).
} 
enunciado tem incluído as noções de civilização e de cultura, preponderantes enquanto elementos de motivação para que as pessoas façam o deslocamento para outros locais, havendo assim, nomeadamente, um alargamento da noção de turismo (COSTA, 2005).

A sociedade aristocrática europeia do século XVIII realizava viagens por prazer - o Grand Tour, motivada pela necessidade de desenvolvimento pessoal. Os viajantes deslocavam-se pelo continente em busca de arte, cultura e das raízes da civilização ocidental, mantendo o contato com outros povos, civilizações e culturas. Nesse sentido, o Grand Tour, enquanto fenômeno social, pode ser entendido como uma matriz remota para o conceito contemporâneo de Turismo Cultural.

Mais adiante, no século XIX, o britânico Thomas Cook organizava as primeiras viagens coletivas de que se tem conhecimento. O empresário vendia pacotes turísticos para viagens, cujo objetivo principal era a motivação para o alívio do stress cotidiano, causado pelo modo de vida do período industrial. Segundo Julião (2012, p. 20), "essas viagens propiciavam aos turistas um contato com os ambientes rurais ingleses e com as formas de vida que originaram a sociedade britânica (countryside)".

A Organização Mundial do Turismo (OMT, 1998) identifica o turismo cultural como sendo o movimento de pessoas, essencialmente por motivos culturais, incluindo visitas de grupo, visitas culturais, viagens a festivais, visitas a sítios históricos e monumentos, folclore e peregrinação. Trata-se de um segmento do turismo dentre outros existentes, como o ecológico, o religioso, o arqueológico, o de aventura, o de negócio, entre outros. Ainda segundo a OMT, o turismo cultural é visto como o mercado que mais cresceu ao nível global e cresce mais de $5 \%$ ao ano do que o turismo global (WORLD TOURISM ORGANIZATION [WTO], 2012).

Richards (2008) definiu turismo cultural enquanto o movimento de pessoas para atrações culturais em ambientes externos aos seus, cuja intencionalidade estaria em reunir novas informações e experiências, de modo a satisfazer certas necessidades culturais. Esse conceito coaduna com Beni (2001), que entende o turismo cultural como uma afluência de turistas a núcleos receptores que oferecem como atrativo essencial o legado histórico do homem em distintas épocas, representado a partir do patrimônio e do acervo cultural.

Para Santos e Antonini (2004), o turismo cultural é um dos fenômenos mais importante dos últimos tempos, pois tem a capacidade de proporcionar um contato e uma troca de experiências entre culturas distintas, o que também possibilita uma globalização da cultura. Nesse sentido, o turismo cultural passaria a oferecer condições de suporte e de acesso dos recursos herdados. Barreto (2006) aponta que o turismo cultural seria aquele que não tem como atrativo principal um recurso natural, mas sim, as coisas feitas pelo homem, com o objetivo de se conhecer os bens materiais e imateriais que ele mesmo tem produzido.

Entretanto o turismo cultural não deve levar ao entendimento generalizado de que faz uso unicamente dos bens construídos, como edifícios, sítios e monumentos históricos. O turismo cultural inclui os produtos e serviços, a gastronomia, o folclore e as manifestações populares, a arte e o artesanato, entre outros. Tal entendimento vem ao encontro das políticas públicas nacionais, uma vez que o Ministério do Turismo adotou o conceito de turismo cultural compreendido como: "as atividades turísticas relacionadas à vivência do conjunto de elementos significativos do patrimônio histórico e cultural e dos eventos culturais, valorizando e promovendo os bens materiais e imateriais da cultura" (BRASIL, 2006, p. 13).

O turismo e a cultura têm relação de dependência, visto que boa parte dos turistas, ao escolherem seus destinos, procuram e consomem manifestações culturais e patrimoniais. Moletta 
(1998) considera que o turismo cultural é também promover o acesso a um patrimônio, ou seja, à história, à cultura e ao modo de viver de uma comunidade. Sendo assim, o turismo cultural vai além da noção da viagem motivada pelo lazer e repouso; caracteriza-se enquanto um fenômeno social que permite ao turista conhecer lugares onde o foco central das atividades turísticas é planejado a partir das bases históricas de um determinado povo, incluindo suas tradições e manifestações populares.

Diante do exposto, percebe-se que o patrimônio cultural exerce papel de grande importância para o consumo de destinos turísticos. Entretanto deve-se respeitar a necessidade de que a própria população local construa de maneira planejada uma relação de pertencimento com o seu legado cultural, evitando que o patrimônio seja tratado como categoria de mercadoria para o turismo.

A participação da comunidade local é o primeiro passo a ser respeitado, quando se buscam ações para a salvaguarda e para o reconhecimento dos legados culturais. Camargo (2002, p. 97) aponta que "atrativos culturais devem estar voltados principalmente para o lazer das populações ou cidadãos da própria localidade, condição para uma futura e eventual apropriação pelo turismo", ou seja, para que determinado bem possa ser utilizado pela atividade turística, antes de tudo precisa ser reconhecido pela população local. É essencial, ao propor que um lugar se abra para o turismo, que os habitantes tenham muita clareza daquilo com que se identificam e que querem mostrar, tendo-se, inclusive, o conhecimento do impacto que essa exposição poderá acarretar para as suas vidas.

Destarte, o patrimônio cultural, sendo considerado por determinado grupo social como sua própria cultura, sustenta sua identidade e o diferencia de outros grupos. Assim, ao propor o turismo cultural para um determinado lugar, a população local deve ter clareza daquilo que deseja mostrar, visto que o desejo de se desenvolver um turismo ligado à cultura deve emanar da própria população local, à medida que essa se sinta sensibilizada e valorize seu próprio legado.

\subsection{Turismo e desenvolvimento local}

Sabendo que o turismo é a atividade de maior crescimento no mundo (Beni, 2001) e que traz possibilidades de atração de investimentos para o local, ocasionando um efeito multiplicador da economia (HAMMERL; SILVEIRA, 2013), propõe-se que o planejamento turístico de um determinado espaço esteja voltado ao seu desenvolvimento regional (OLIVEIRA; LIMA, 2003).

O desenvolvimento local é aquele realizado em pequenos lugares de forma participativa, levando a mudanças socioestruturais, com caráter endógeno. Nele, os habitantes possuem relativa autonomia, para explorar o potencial do território que beneficie a maioria deles, e decidir como cada um pode contribuir com inovações. São os residentes os agentes principais do desenrolar de todo processo de desenvolvimento e zelam pela qualidade dos relacionamentos interpessoais, interinstitucionais, aproveitam as sinergias em benefício da coletividade. (CORIOLANO, 2012, p. 133).

Becker (2001) aponta que o turismo seria o grande marco do século, para acelerar o desenvolvimento local. Diante dessa observação, o planejamento do turismo tende a estimular a oferta e a demanda de serviços locais, criando empregos, renda, fomentando dessa forma a economia e o desenvolvimento.

Nessa acepção, as questões locais passam a assumir importância cada vez maior para o planejamento do turismo, entendendo que o local é um espaço vivido e sentido pelos seus habitantes (FRÉMONT, 1980), à medida que as regiões vêm se tornando protagonistas de seu próprio 
desenvolvimento. Assim, falar de desenvolvimento local seria determinar, nomeadamente, um território constituído por uma identidade e uma consciência regional.

Segundo Gil, Oliva e Silva (2009, p. 97), o sentido de região estaria, então, vinculado ao lugar, constituído por indivíduos que habitam ou habitaram seus espaços e neles imprimiram a sua cultura. Nesse sentido, uma região passaria a ser uma apropriação simbólica de um determinado espaço pelas pessoas que nele vivem e contribuem para a constituição de sua identidade.

Quando se fala de "local", está-se referindo à escala das inter-relações pessoais da vida cotidiana, que sobre uma base territorial constroem sua identidade. O lugar é essa base territorial, o cenário de representações e de práticas humanas que são o cerne de sua singularidade; o "espaço de convivência humana", onde se localizam os desafios e as potencialidades do desenvolvimento. (MARTíN apud MARTINS, 2002, p. 54)

Para Santos (2008, p. 46), o espaço é observado como:

[...] algo dinâmico e unitário, onde se reúnem materialidade e ação humana. O espaço seria o conjunto indissociável de sistemas de objetos, naturais ou fabricados, e de sistemas de ações, deliberadas ou não. A cada época, novos objetos e novas ações vêm juntar-se às outras, modificando o todo, tanto formal quanto substancialmente.

Diante do exposto, o local seria um espaço delimitado por fatores de identificação dos seus agentes, e que nele se sentiriam pertencidos, haja vista suas singularidades e especificidades. $O$ conceito de local também inclui a região onde os seus habitantes convivem harmoniosamente e que por meio das suas relações imprimem sua cultura, constituindo sua identidade. Sendo assim, o desenvolvimento de uma determinada região tem se alicerçado na premissa de que o seu território possui uma relação com a cultura e a identidade local, transformando-se no patrimônio do lugar. Por isso, podemos também considerar o espaço e o seu desenvolvimento numa perspectiva de utilização turística, permeado por ações endógenas, num primeiro momento.

\subsection{Planejamento do turismo no espaço rural}

Para assegurar que o turismo se desenvolva parcimoniosamente de forma sustentável, deve-se pensar no seu planejamento. Desse modo, o planejamento do turismo deve prever a utilização de recursos naturais e culturais a serem explorados sem destituí-los de sua autenticidade, preservando-os para gerações futuras. Para Oliveira (2005), o turismo não pode se organizar e se desenvolver sem que haja planejamento e definição de objetivos a serem alcançados.

Também, o planejamento do turismo deve estar associado a ações que envolvam o desenvolvimento do local de forma integral. As ações isoladas acabariam por promover um desequilíbrio, acarretando em mais impactos negativos no território do que propriamente o desenvolvimento do local. Para tanto, faz-se necessário o planejamento do turismo

Segundo Ruschmann (1997, p. 83), planejamento turístico é entendido como:

Uma atividade que envolve a intenção de estabelecer condições favoráveis para alcançar objetivos propostos. Ele tem por objetivo o aprovisionamento de facilidades e serviços para que uma comunidade atenda seus desejos e necessidades ou, então, o "desenvolvimento de estratégias que permitam a uma organização comercial visualizar oportunidades de lucro em determinados segmentos de mercado".

No território rural, diferentes estratégias de desenvolvimento têm sido percebidas, desde que os proprietários desses espaços não conseguiram se adequar às mudanças influenciadas pela 
modernização no campo. Também o êxodo rural, ocorrido a partir da década de 60, provocou um esvaziamento de população dessas cidades, a partir do movimento migratório que ocorreu. Nessa conjuntura, o turismo no espaço rural emergiu no cenário brasileiro visando a estratégias para o desenvolvimento de práticas para uma subsistência local.

Nos últimos anos, o êxodo rural ocasionou uma nova articulação territorial, abrindo caminhos a diferentes opções de desenvolvimento, não mais voltado exclusivamente à agricultura e seus meios de produção. Uma alternativa para o desenvolvimento desses espaços seria o turismo e seus desdobramentos, tais como, turismo rural, agroturismo, turismo de natureza, ecoturismo, entre outros. Em todos os casos, é nas suas paisagens e nos do território que estão elementos chave para a valorização e o desenvolvimento turístico dos lugares. (CARVALHO; FERNANDES, 2012, p. 86)

Assim, a própria paisagem passa a ser interpretada como um atrativo turístico, entendendo que ela pode se configurar numa ferramenta útil de desenvolvimento do turismo e do local em si. Da mesma maneira, vale ressaltar que a qualidade estética, ou seja, a singularidade, a autenticidade e a variedade nas composições territoriais são preponderantes ao se planejar o turismo de uma região.

É essencial que os residentes da comunidade estejam envolvidos nas tomadas de decisões e na gestão do turismo, em termos de planejamento e de desenvolvimento (OLIVEIRA, 2005). Para Coriolano (2012), o turismo tem sido uma estratégia de moradores locais- agricultores em sua maioria - e órgãos públicos para o fortalecimento de propriedades e comunidades rurais, gerando, desse modo, novas dinâmicas para esses espaços, antes direcionados unicamente para a produção primária.

Assim sendo, o planejamento do turismo se constitui como o conjunto de todas as ações, decisões e objetivos que se pretende alcançar para desenvolver e/ou incrementar o turismo numa determinada localidade, através de métodos e instrumentos adequados e específicos para atingir tal fim, tendo por base o conceito de sustentabilidade, envolvendo setor público, privado e comunidade.

O planejamento do turismo vem sendo aderido como uma estratégia de novas dinâmicas para o espaço rural, ancorada na perspectiva do desenvolvimento local. Dessa forma, o turismo no espaço rural deve estar alicerçado no planejamento da atividade a partir de ações endógenas, que contribuam para o fortalecimento de comunidades rurais e valorizem os aspectos locais, sejam esses culturais, ambientais e sociais, devendo, ainda, contribuir economicamente para o incremento das referidas ações.

Destarte, a atividade turística relacionada ao desenvolvimento local deverá ter o envolvimento da comunidade, em ações que promovam o retorno para o próprio local, possibilitando condições de que o morador não necessite migrar para outra região e assegurando-lhe melhores condições de vida; além de favorecer o estímulo à valorização de insumos locais, artes e artesanatos e demais atividades associadas ao turismo. (CORIOLANO, 2012, p. 71).

Sob essa perspectiva, uma das tendências para o turismo no espaço rural tem sido o planejamento do turismo, onde os atrativos culturais passam a ser os principais recursos para o seu desenvolvimento. Valorizam-se, assim, o modo produtivo e o modus vivendi local. O turismo cultural seria, portanto, um mecanismo de exploração das potencialidades culturais que um determinado local possui, onde seus agentes têm se identificado coletivamente.

Portanto o turismo cultural contribui para o desenvolvimento de atividades que corroboram com a permanência da população num determinado território. No espaço rural, tem-se obser- 
vado que esse modelo de planejamento e desenvolvimento turístico beneficia a todos, gerando renda com a venda de insumos o que também acarreta em um novo ordenamento dos espaços rurais, propondo, inclusive, novas ruralidades (CARVALHO; FERNANDES, 2012).

No turismo rural, as paisagens exprimem a unicidade e a identidade de cada lugar (genius locci), refletindo tanto a história natural como cultural de um território, num determinado momento. O seu caráter é dinâmico e está continuadamente em mudança, mas é único em cada lugar (PINTO-CORREIA; CANCELA; OLIVEIRA, 2001).

Ao se planejar o turismo, Oliveira (2005) aponta que este pode ser classificado em três níveis, que são: primeiro nível - que busca a utilização de dos recursos naturais ou não naturais já existentes; segundo nível - busca ações de intervenção mais técnicas, transformando-se em um núcleo turístico; terceiro nível: busca estabelecer políticas públicas para o destino turístico.

Tabela 1 - Classificação dos níveis de planejamento do turismo

\begin{tabular}{c|l}
\hline \multicolumn{1}{c}{ Níveis de Planejamento do Turismo } \\
\hline \\
PRIMEIRO \\
NÍVEL & $\begin{array}{l}\text { Oferece aos visitantes a paisagem, as praias e outras atrações com pouca organização para } \\
\text { recepcioná-los. Emprega pouca mão de obra e possui uma infraestrutura básica precária. } \\
\text { cautela e determinação fazendo com que a população do local se motive, compreenda } \\
\text { e se interesse pelo turismo. Se o local possui um patrimônio turístico capaz de ser razão } \\
\text { do seu desenvolvimento, é extremamente importante que a população esteja consciente } \\
\text { de que a sua vida poderá mudar. Se esta mudança ocorrer de forma gradativa, trazendo } \\
\text { benefícios para a população, não haverá dúvida de que o turismo será implantado } \\
\text { corretamente. }\end{array}$ \\
SEGUNDO \\
NÍVEL & $\begin{array}{l}\text { Busca ações de intervenções mais complexas e técnicas. É o momento em que a localidade } \\
\text { se transforma num núcleo turístico interessante. Os recursos preexistentes devem ser } \\
\text { ativados, recuperados ou implantados. Múltiplas ações e decisões precisam ser tomadas. } \\
\text { Leis, regulamentos e projetos apresentam maior grau de complexidade, envolvendo mais } \\
\text { tempo e mais recursos, tendo, também, resultados duradouros. }\end{array}$ \\
\hline TERCEIRO & $\begin{array}{l}\text { Busca estabelecer a política nacional para incentivar a atividade turística no país e } \\
\text { organizá-la, abrangendo inclusive os outros dois níveis. }\end{array}$ \\
\hline NIVEL
\end{tabular}

Fonte: Adaptado de Oliveira (2005).

Ao observar a classificação proposta por Oliveira (2005), pode-se perceber que o planejamento do turismo de uma região parte do primeiro nível, a partir da preocupação com a salvaguarda dos patrimônios legados, naturais e culturais. O importante é a identificação e a promoção das paisagens que contam com a oferta de pouca infraestrutura turística, incipiente e isolada. É a partir da identificação do sujeito com o local que se desencadeará toda uma programação para o planejamento do turismo, alçado nos interesses da própria população local, a mais beneficiada por isto. O planejamento do turismo tem por premissa o desenvolvimento sustentável racional do turismo sem deteriorar o meio ambiente, pelo contrário, ele surge como uma alternativa preservacionista.

No segundo nível do planejamento do turismo, é o momento em que ele começa a se organizar e se promover, de forma profissional. Para tanto, surgem ações mais técnicas e complexas, o que o transforma em núcleo turístico. Cabe observar o poder público presente, sustentando 
o planejamento do turismo por meio das políticas públicas que começam a ser instituídas. Tais medidas assumem o papel de grande importância, visto que, a partir desse momento, as ações de planejamento do turismo obtêm resultados mais duradouros.

Por último, o terceiro nível abrange os outros dois níveis de planejamento do turismo, buscando estabelecer a política nacional para incentivar o fomento do turismo na região. Este seria, portanto, o nível em que o destino turístico ou a região turística já estaria efetivamente consolidado.

De acordo com Lage e Milone (2000), o planejamento turístico está dividido em algumas etapas, a saber:

- Inventário de todos os recursos turísticos naturais e culturais;

- Análise e síntese da situação encontrada;

- Formulação da política e do plano de turismo e também de recomendações de viabilidade

- Controle da gestão do processo total (LAGE; MILONE, 2000, p. 165).

Diante do exposto, esta pesquisa buscou evidenciar os atrativos turísticos das cidades que atualmente compõem o antigo território do Caminho das Tropas. A partir disso, a pesquisa listou os principais atrativos encontrados, já explorados turisticamente ou não, observou a situação atual deles e, também, apontou algumas sugestões para a sua exploração turística, cujo intento é instituir um roteiro regional com foco no turismo cultural do antigo caminho traçado entre o litoral e o planalto catarinense.

\section{METODOLOGIA}

O presente artigo aborda dois importantes temas na literatura sobre o setor do turismo, a saber, patrimônio cultural e planejamento turístico. A partir do estudo de caso sobre o Caminho das Tropas, faz-se a correlação dessas duas temáticas cuja finalidade foi a de se pensar o planejamento turístico de um determinado território. Trata-se, portanto, de uma pesquisa exploratória e analítica, realizada a partir de dados bibliográficos e documentais. Em um primeiro momento, foram levantados dados historiográficos da região, recorrendo-se à literatura clássica e a textos de pesquisadores que tenham tratado de aspectos históricos, sociais e culturais da região e das cidades que integram o Caminho das Tropas, em Santa Catarina. A partir dessa leitura inicial, foi realizado um levantamento dos primeiros indicativos patrimoniais do antigo percurso do Caminho das Tropas Desterro-Lages, conforme o quadro-síntese a seguir: 
Tabela 2 - Pesquisa bibliográfica

\begin{tabular}{l|l|l|}
\hline \multicolumn{3}{c}{ Pesquisas e Publicações sobre o Caminho das Tropas Desterro-Lages } \\
\hline \multicolumn{1}{c|}{ Autor e ano } & \multicolumn{1}{|c|}{ Assunto } & \multicolumn{1}{c|}{ Tipo publicação } \\
\hline Luz (1952) & História e formação do território catarinense & Livro \\
\hline Piazza (1971) & História e formação do território catarinense & Livro \\
\hline Jochem (1992; 1997) & $\begin{array}{l}\text { Formação do território das colônias alemãs de São Pedro de } \\
\text { Alcântara (1829) e Santa Isabel (1847), aspectos históricos } \\
\text { e culturais. }\end{array}$ & Livro \\
\hline Werner (2004) & $\begin{array}{l}\text { Levantamento histórico do Caminho das Tropas e história } \\
\text { de sua pavimentação, construção da BR 282 }\end{array}$ & Livro \\
\hline $\begin{array}{l}\text { Brüggemann (2008; } \\
\text { 2011; 2013) }\end{array}$ & $\begin{array}{l}\text { História e formação do território da Colônia Militar de Santa } \\
\text { Tereza (1853) }\end{array}$ & $\begin{array}{l}\text { Livro e dissertação } \\
\text { de mestrado }\end{array}$ \\
\hline $\begin{array}{l}\text { Bauer (2011; 2012; } \\
\text { 2015a; 2015b) }\end{array}$ & $\begin{array}{l}\text { Aspectos históricos e culturais de Angelina (SC) e Rancho } \\
\text { Queimado (SC); pesquisas sobre tropeirismo, patrimônio } \\
\text { imaterial }\end{array}$ & Artigos na internet \\
\hline
\end{tabular}

Fonte: Elaborada pelos autores.

Orientando-se pelos autores supracitados, pode-se apresentar dados para a descrição do Caminho das Tropas Catarinense e para o diagnóstico das potencialidades turísticas da região.

\section{RESULTADOS}

Durante o século XVII, as vilas litorâneas catarinenses estabeleciam contatos e trocas comerciais entre si por meio da navegação marítima, no entanto não havia comunicação com o planalto serrano paulista, onde se localizava a vila de Lages. O espaço entre o litoral e planalto, então desconhecido, era denominado por "sertão", ou seja, "lugar de risco e perigo, terra de inimigos e bichos indomáveis" (BRÜGGEMANN, 2008, p. 51). O interior precisava ser explorado, e havia a necessidade de povoá-lo, além de se descobrir suas riquezas.

Nesse sentido, foi traçado um projeto de ocupação para a região, surgindo a formação dos primeiros povoados. A primeira incursão mata adentro, sentido litoral-planalto, data de 1787 , denominada de "Picada do Alferes", e seguia de São José da Terra Firme (atual São José), pelas margens do Rio Maruim, passando pelas colônias de São Pedro de Alcântara (primeira colônia alemã de Santa Catarina) e Vila Mundéus (atual Angelina), de onde partia para a localidade do Alto Garcia, alcançando Taquaras, última linha colonial da Colônia Santa Isabel e segunda colônia alemã do Estado; dali seguia pela Serra do Trombudo e Morro da Boa Vista (ambos em Bom Retiro), até chegar ao Rio Canoas, nas proximidades da Vila de Lages (BAUER, 2012; BRÜGGEMANN, 2008; JOCHEM, 1992). 
Figura 1 - Mapa Caminhos de Tropas

\section{CAMINHOS DE TROPAS}

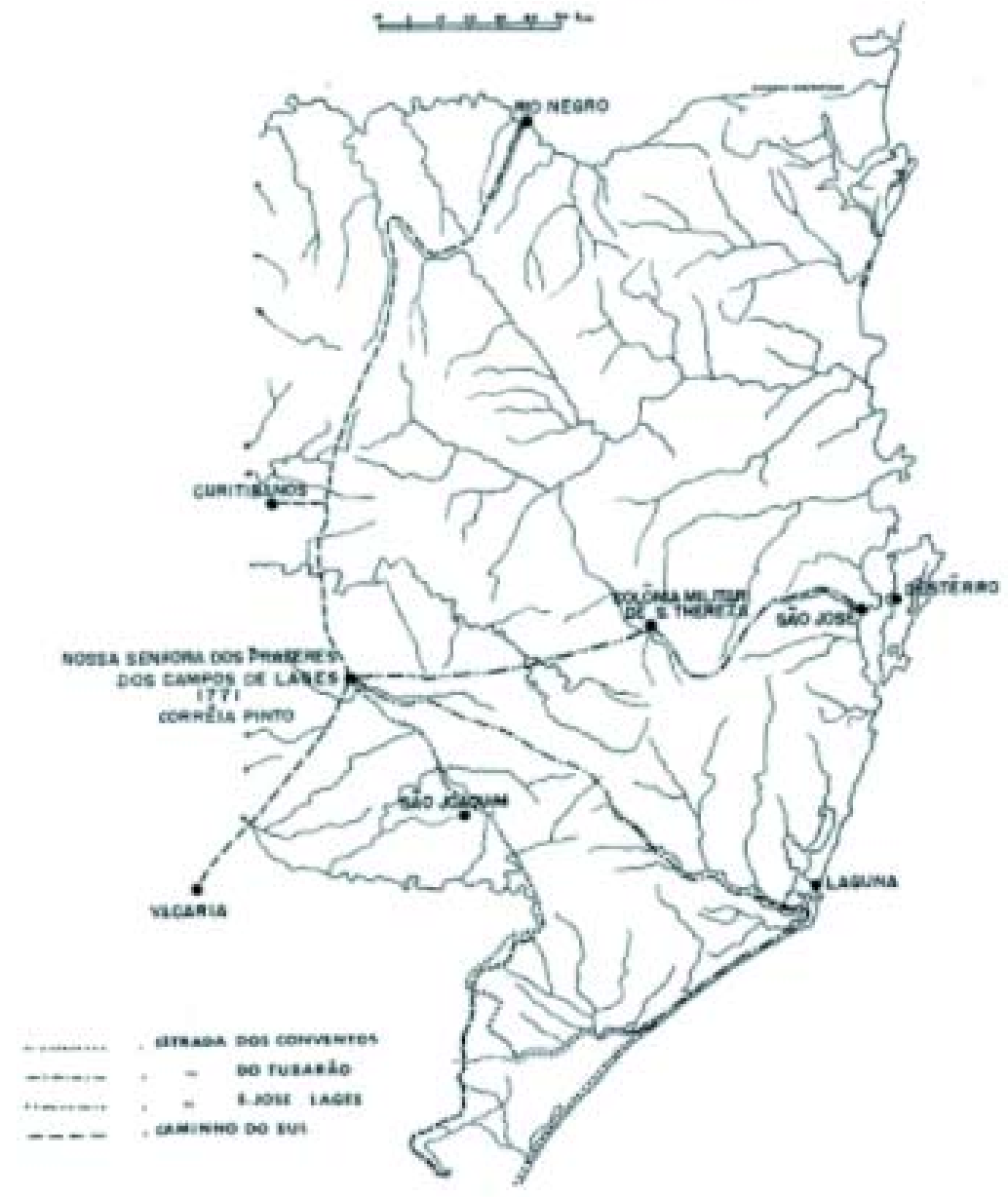

Fonte: Piazza (1971)

Bauer (2015a) aponta que a abertura de uma ligação terrestre entre o litoral e o planalto serrano paulista criou uma importante rota comercial, denominada por "Caminho das Tropas", por onde se observou uma intensa transformação sociocultural, desde a sua implantação. Para que houvesse a manutenção e a segurança desse caminho, o governo da província de Santa Catarina promoveu a instalação de colônias pelo seu traçado, a saber, as colônias alemãs de São Pedro de Alcântara (1829) e de Santa Isabel (1847), a militar de Santa Tereza (1853) e a de açorianos, advindos do litoral, Colônia Nacional de Angelina (1860).

Atualmente, integram o traçado original do Caminho das Tropas, iniciado em 1797, os municípios de São José, São Pedro de Alcântara, Águas Mornas, Angelina, Rancho Queimado, Alfredo Wagner, Bom Retiro, Bocaina do Sul e Lages. O modus vivendi dos tropeiros - o tropeirismo, ainda hoje pode ser fortemente identificado nas culturas locais dessas cidades, por meio das culturas miscigenadas que ali foram se constituindo ao longo da história. A cidade de Rancho Queimado, por exemplo, foi fundada por imigrantes alemães, mas tem a origem do seu nome herdada dos tropeiros: segundo relatos, era naquela região que eles pernoitavam e, por um incêndio fortuito, o rancho de pouso acabou se incendiando. 
Figura 2 - Traçado da primeira rota dos Caminho das Tropas e municípios atuais


Fonte: Elaborada pelos autores.

\section{O CAMINHO DAS TROPAS DESTERRO-LAGES: PATRIMÔNIOS, ATRATIVOS TURÍSTICOS E TURISMO CULTURAL}

É comum observar estudos sobre a relação entre o patrimônio e a atividade turística, denominado por Turismo Cultural. A Organização Mundial do Turismo (1998) sugere a definição dos chamados patrimônios turísticos, ao definir que "património turístico es el conjunto de bienes materiales e inmateriales que constituyen la materia prima que hace posible el desarollo del turismo" (SCHLÜTER; NORRILD, 2002, p. 37).

É importante considerar que o desenvolvimento do turismo cultural se inicia pela valorização e promoção da própria cultura local, preservando os seus patrimônios e gerando oportunidades de renda no setor. Nessa perspectiva, o patrimônio não é um simples atrativo turístico, mas sim, um fator capaz de destacar, preservar e oferecer subsídios para compreender a própria identidade cultural de uma comunidade, por experiências vividas entre grupos distintos. As diversas combinações da cultura e do turismo configuram o segmento de Turismo Cultural, que é marcado pela motivação do turista de se deslocar especialmente com a finalidade de vivenciar os aspectos e situações que são peculiares da nossa cultura" (BRASIL, 2006, p. 11).

Diante do exposto, fez-se pertinente o levantamento de potencialidades para a proposição de um roteiro turístico cultural sobre o Caminho das Tropas, visto que, apesar da sua importância na historiografia catarinense, esse caminho esteve sempre em segundo plano, sobreposto a outras culturas, em especial a alemã. Nesse sentido, a partir de um levantamento histórico sobre o Caminho das Tropas, poderemos evidenciar alguns atrativos que corroborariam com o desenvolvimento de um turismo cultural sobre os tropeiros que abriram a primeira rota mercantilista entre Desterro e Lages.

Assim sendo, a preservação do patrimônio cultural nas cidades que integram essa rota dos tropeiros, iniciada em 1787, sob a perspectiva de um desenvolvimento turístico, poderia, 
de certa maneira, desenvolver economicamente essa região, visto que o turismo é a atividade de maior crescimento no mundo (BENI, 2001) e traz possibilidades de atração de investimentos para o local, acarretando um efeito multiplicador da economia (HAMMERL; SILVEIRA, 2013).

Segundo Becker (2001), o turismo é marco do século para acelerar o desenvolvimento regional, estimulando a oferta e a demanda de serviços locais criando empregos, renda e fomentando a economia regional e o seu desenvolvimento. Nesse sentido, esta pesquisa pretende apresentar alguns atrativos turísticos que possuem ligação histórica com a abertura do Caminho das Tropas Desterro-Lages, a saber, bens de referência patrimoniais, tais como, construções históricas, paisagens naturais e culturais.

Um mapeamento de atrativos turísticos das cidades que integram a primeira rota mercantilista entre a capital da província da Capitania de Santa Catarina e a vila de Lages, se apresenta como uma possibilidade concreta de atividade a ser trabalhada nas comunidades locais. Trata-se, portanto, de uma estratégia de preservação do patrimônio, conduzindo a melhoria da qualidade de vida da população envolvida e uma garantia para o fortalecimento de sua identidade cultural e de suas memórias (VIANNA; HOFFMANN, 2012), entendendo que a força do lugar reside no território compartilhado e identificado por uma consciência social e comunitária de entorno, cuja essência é a própria história vivida em comum (SANTOS, 1996; LE BOURLEGAT, 2000).

\subsection{Levantamento de atrativos turísticos do Caminho das Tropas Desterro-Lages}

O turismo passa a ser compreendido como um importante fator do desenvolvimento regional (GIL; OLIVA; SILVA, 2009), uma vez que permite estabelecer relações entre a identidade e a memória, sustentando um turismo comprometido com valores históricos e culturais. $\mathrm{O}$ patrimônio tem uma relação memorial com o lugar (CHOAY, 2001) e os recursos culturais são tradutores de uma forte identidade construída ao longo da sua história; desempenhando funções na formação da imagem e da identidade da localidade (HENRIQUES, 2003).

A freguesia de São José da Terra Firme, atual município de São José, foi uma das primeiras freguesias criadas em Santa Catarina, em 1751. Como a capital da província se localizava numa ilha, São José se beneficiou economicamente do Caminho das Tropas. Por ordem do Governador da Capitania, em 11 de janeiro de 1787, o Alferes Antônio José da Costa ficou encarregado de abrir um caminho entre a freguesia de São José de Terra Firme até as cercanias da vila de Lages, no então planalto serrano paulista. A empreitada do alferes teve início em 11 de janeiro de 1787, quando partiu de São José com "12 homens armados, 12 escravos e 7 bestas cargueiras", seguindo pela picada sul em direção a oeste, margeando o Rio Maruim (COELHO, 1856).

O centro histórico de São José possui um conjunto de casario do período colonial açoriano, tombado como patrimônio histórico e cultural do município, pelo Decreto n. 18.699/2005 (SÃO JOSÉ, 2005a). Trata-se de seis casas geminadas que pertenceram a líderes políticos e comerciantes daquela época. Algumas delas ficaram marcadas pelo vínculo com fatos históricos de grandes vultos, como a do General Xavier Neves, que abrigou o casal imperial no ano de 1845. Outra casa desse conjunto arquitetônico, o Solar Ferreira de Mello, foi um dos primeiros bens tombados pelo estado (P.T. n. 007/86) e abriga o atual Museu Histórico de São José. Ainda no Centro Histórico de São José, mantêm-se preservadas outras construções históricas significativas, tais como a Igreja Matriz (1750), o Theatro Adolfo Mello (1856) e o Beco da Carioca (1750), primeira fonte de água encontrada pelos fundadores, que, do mar, aportaram em terra firme.

INTERAÇÕES, Campo Grande, MS, v. 19, n. 3, p. 655-677, jul./set. 2018 
Outra edificação histórica que se destaca no município de São José é a Ponte do Rio Maruim, construída em 1857, como parte do projeto para uma segunda rota para o Caminho das Tropas. Denominado de "estrada nova", esse caminho promoveu um desvio do trajeto inicialmente traçado, o que acabou isolando a Colônia de São Pedro de Alcântara e de Angelina, desagradando os moradores daquela região. Em 1995, a ponte foi destruída por enchente, restando apenas parte de sua cabeceira - atual Píer do Rio Maruim, tombado pelo Decreto n. 18.703/2005 (SÃO JOSÉ, 2005b) como patrimônio histórico e cultural de São José.

Figura 3- Atrativos turísticos do município de São José: Theatro Adolfo Mello, Centro Histórico, Igreja Matriz, Píer do Rio Maruim, Beco da Carioca e vista noturna da cidade

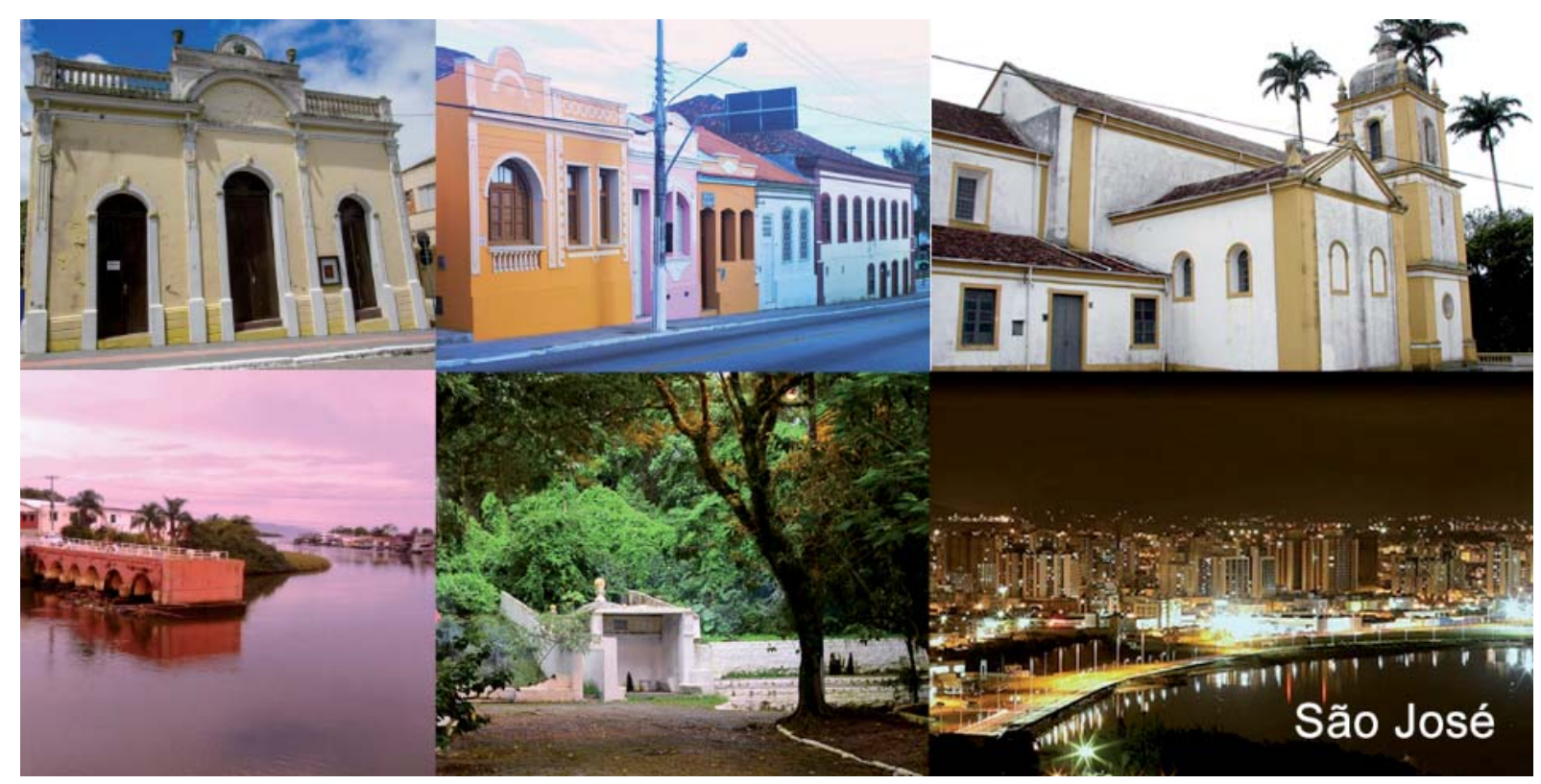

Fonte: Elaborada pelos autores.

Motivado pela necessidade de se povoar a rota comercial recém-aberta, o governo dá início ao processo de colonização da região. Em 1829, funda a primeira colônia alemã do estado de Santa Catarina, São Pedro de Alcântara. A cidade, com 4704 habitantes (INSTITUTO BRASILEIRO DE GEOGRAFIA E ESTATÍSTICAS [IBGE], 2015), preserva as características de origem germânica e tem se promovido turisticamente sob essa perspectiva, junto com as cidades de Águas Mornas e Rancho Queimado, que integram a Rota Caminhos da Imigração Alemã.

São Pedro de Alcântara mantém preservada uma parcela significativa do Caminho das Tropas, conhecido por Caminho do Salto e tombado pelo município, por meio da Lei Ordinária n. 297/2004 (SÃO PEDRO DE ALCÂNTARA, 2004). O trajeto, construído pelos escravos, possui aproximadamente 1000 metros pavimentados com pedras em estilo 'pé-de-moleque'. Outro importante marco histórico do antigo Caminho das Tropas localizado em São Pedro de Alcântara trata-se da Pedra das Letras, um petróglifo indicativo da passagem dos tropeiros pelo local. Datado de 12 de maio de 1789, possui as inscrições de uma cruz de malta junto com as iniciais VRDP, que, segundo historiadores, significaria Viva o Rei de Portugal.

Ao longo do Caminho das Tropas pela colônia alemã de São Pedro de Alcântara, o comércio foi se estabelecendo entre os imigrantes e os tropeiros. Algumas casas comerciais continuam ainda preservadas, como o conjunto arquitetônico Vila Kretzer, tombado como patrimônio 
histórico cultural, em nível estadual, pelo Decreto n. 5.979/2002 (FUNDAÇÃO CATARINENSE DE CULTURA, 2002). Outro exemplo é um antigo armazém, também tombado pela municipalidade, pela Lei Ordinária n. 011/1999 (SÃO PEDRO DE ALCÂNTARA, 1999) e que atualmente abriga um museu histórico regional, a Casa Cultural São Pedro.

Figura 4 - Atrativos turísticos do município de São Pedro de Alcântara: Portal Turístico, Casa Cultural São Pedro, Caminho do Salto, Vila Kretzer e Igreja Matriz

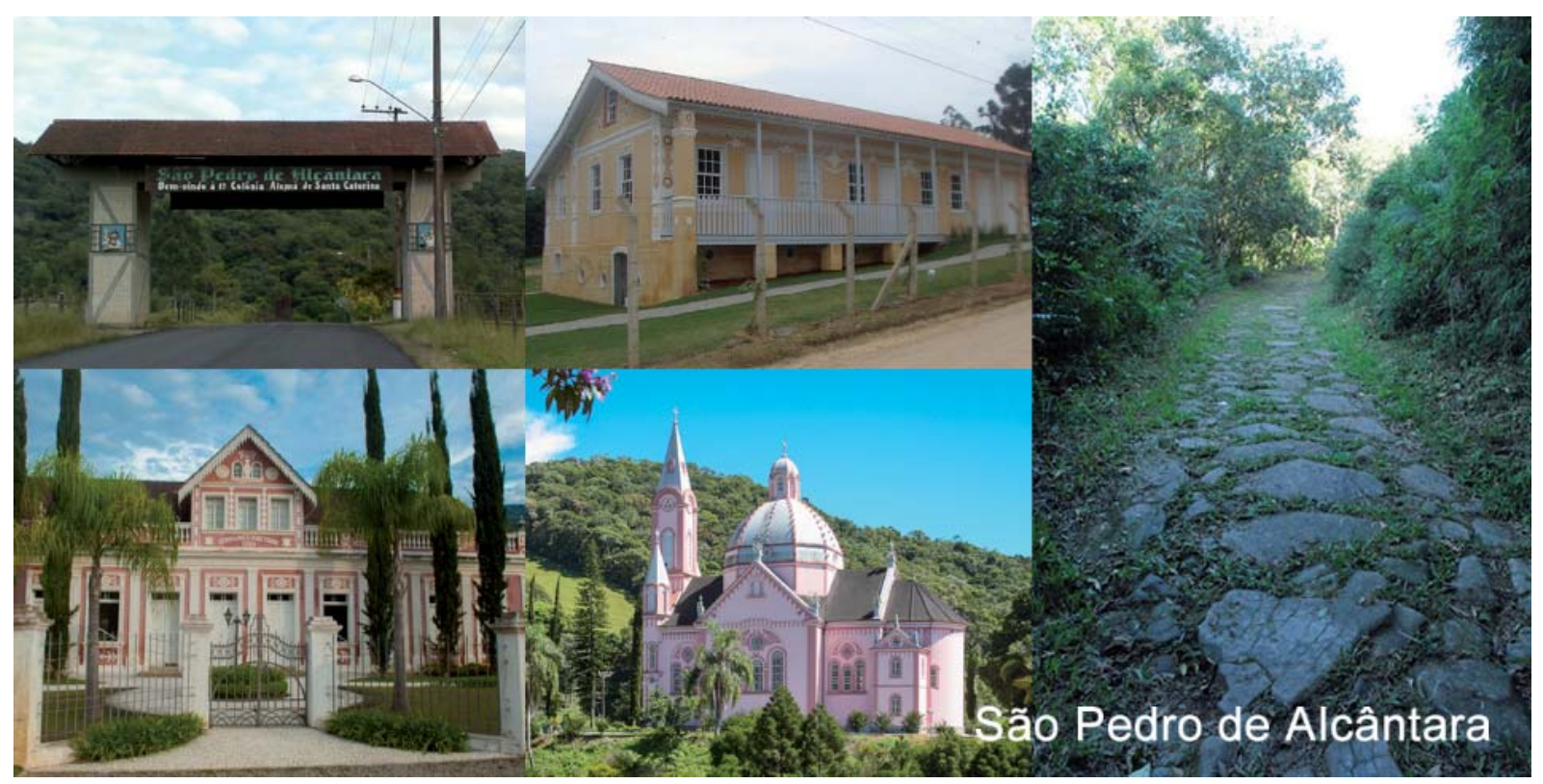

Fonte: Elaborada pelos autores.

A fundação da Colônia Nacional de Angelina, em 1860, se iniciou com açorianos e seus descendentes, que trocaram o litoral catarinense pelo interior do sertão. Já nos primeiros anos da sua instalação, a colônia sofreu com problemas financeiros, motivada pela falta de investimentos do governo e pelo abandono geográfico sofrido, quando o Caminho das Tropas mudou seu trajeto inicial (WERNER, 2004; JOCHEM, 1992).

A religiosidade sempre esteve presente na colônia, e, em 1863, foi construída sua primeira igreja. Angelina ficou reconhecida como um destino de turismo religioso, integrando o roteiro turístico Caminhos da Fé. A cidade possui locais de peregrinação, como o Santuário Nossa Senhora de Angelina, composto pela Gruta Nossa Senhora de Lourdes, inaugurada em 1907. Logo após conclusão da gruta, foram encomendados na Alemanha os quadros da Via Sacra para a gruta, que chegaram em Desterro em quatro grandes caixotes de madeira. Para facilitar o transporte até Angelina, as caixas são abertas e os catorze blocos de gesso, medindo $85 \mathrm{~cm}$ de altura por $60 \mathrm{~cm}$ de largura, são levados em carroças, pelo Caminho das Tropas, com a ajuda dos colonos da região (BAUER, 2011). 
Figura 5 - Atrativos turísticos do município de Angelina: Museu da Congregação das Irmãs Franciscanas, Gruta Nossa Senhora de Lourdes, Via Sacra (XII Estação: Jesus morre na cruz), Convento Irmãs Franciscanas e Igreja Matriz

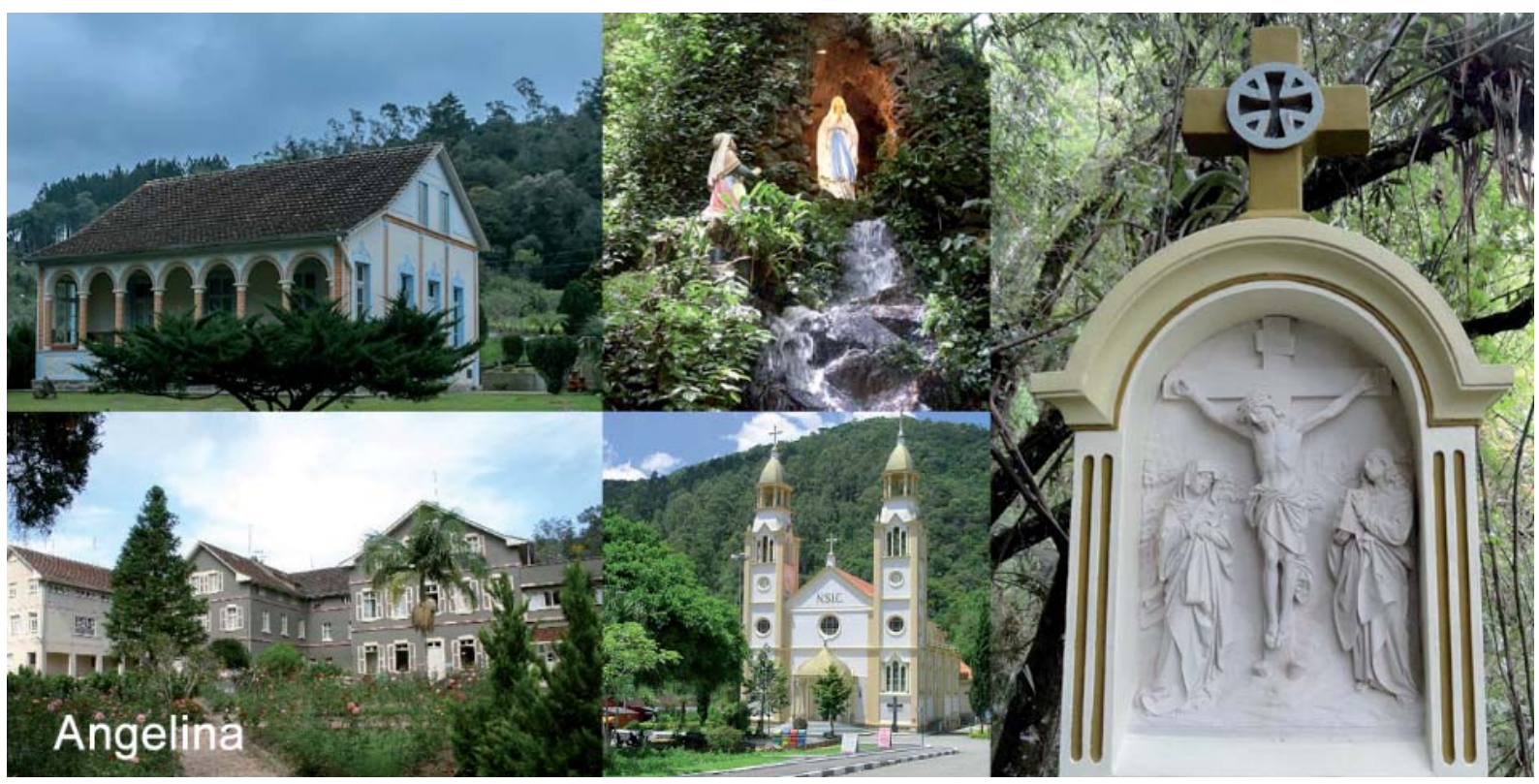

Fonte: Elaborada pelos autores.

Partindo de Angelina, o Caminho das Tropas chegava a Rancho Queimado, alcançando a comunidade de Taquaras, última linha colonial da Colônia de Santa Isabel. Luz (1952) descreve que, até 1901, a estrada das tropas só chegava até Taquaras; daí para adiante, só se podia viajar a cavalo, gastando mais quatro dias para se chegar a Lages. A primeira estrada só foi completada cinco anos depois, em 1906. Taquaras ocupou papel de destaque na historiografia do Caminho das Tropas, visto que, apesar das mudanças de trajeto que ocorreram ao longo dos tempos, o lugar sempre foi um ponto de intersecção (BAUER, 2012; BRÜGGEMANN, 2008; JOCHEM, 1992).

Apesar de Rancho Queimado e suas localidades terem sido linhas coloniais alemãs, pode-se notar influências do tropeirismo, enquanto legado histórico e cultural do antigo Caminho das Tropas. Em 1993, a cidade construiu o Monumento ao Tropeiro e instituiu a Festa do Tropeiro em seu calendário de eventos. Pela cidade há trechos ainda pavimentados do antigo Caminho das Tropas, contudo nenhum possui registro de tombamento nem se configura como atrativo turístico. O único bem tombado em nível estadual (P.T. n.: 006/84), diz respeito à Antiga Casa de Campo do Governador Hercílio Luz e abriga um Museu Histórico, administrado pela Fundação Catarinense de Cultura. 
Figura 6 - Atrativos turísticos do município de Rancho Queimado: Mirante da Boa Vista (1.200m), Portal Turístico, Monumento ao Tropeiro, Tropeada (Festa do Tropeiro) e Museu Casa de Campo Governador Hercílio Luz

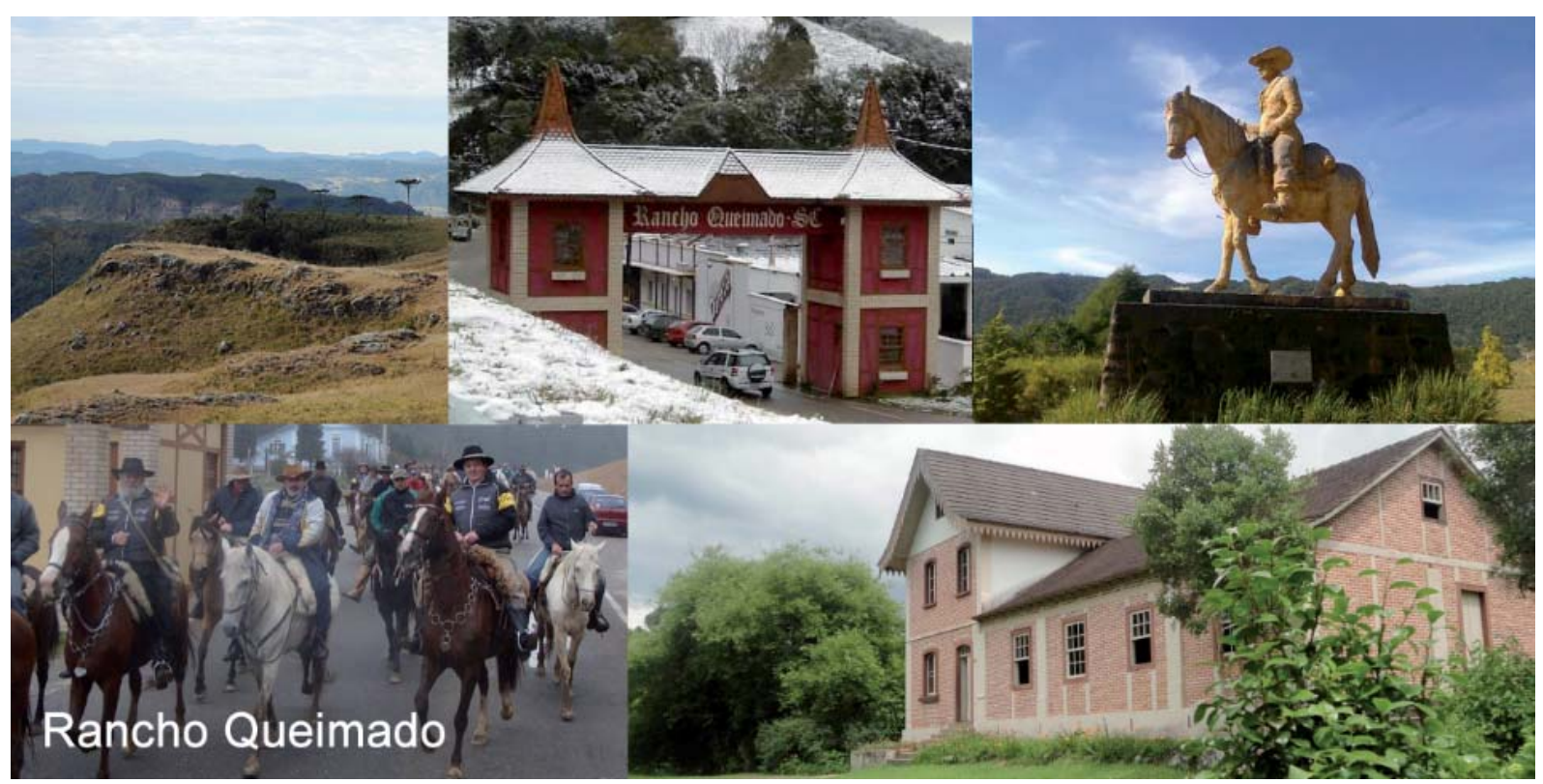

Fonte: Elaborada pelos autores.

Em Taquaras, o Caminho das tropas seguia pelos morros da Boa Vista, até alcançar onde hoje se situa o município de Alfredo Wagner, a Colônia Militar de Santa Tereza, fundada em 1853. Segundo Brüggemann (2011), o estabelecimento dessa colônia se devia, principalmente, a dois motivos. Primeiro, proteger os viajantes e os tropeiros que utilizavam o caminho; segundo, cobrar impostos sobre todos os animais e mercadorias que por ali passavam. Sua localização foi considerada estratégica, no Morro do Trombudo, com 1306 metros de altitude, local onde o alferes Antônio José da Costa demarcara ainda em sua primeira expedição, em 1787, o limite entre as capitanias de Santa Catarina e São Paulo (WERNER, 2004; BRÜGGEMANN, 2013).

De Alfredo Wagner, o Caminho das Tropas alcançava os campos da Boa Vista, já em terras da Capitania de São Paulo. O território foi posteriormente requerido pela capitania de Santa Catarina e, em 1820, o território entre os campos da Boa Vista até a vila de Lages a ela foram incorporados (LUZ, 1952). O Morro da Boa Vista é o ponto mais alto de Santa Catarina, com 1.827 metros, e se localiza no limite entre os municípios de Bom Retiro e Urubici. Ainda em Bom Retiro, outro atrativo turístico pode ser identificado, a saber, a Calçada do morro Costão do Frade, um trecho pavimentado do antigo Caminho das Tropas, semelhante aos já identificados em São Pedro de Alcântara e Rancho Queimado. Outro atrativo turístico da cidade de Bom Retiro é o Monumento ao Capitão Antônio Marques Arzão, fundador da cidade e membro do grupo que, junto com o alferes Antônio José da Costa, abriu o Caminho das Tropas. 
Figura 7 - Atrativos turísticos do município de Bom Retiro: Morro da Boa Vista (1.827m), Calçada, Monumento Antônio Marques Arzão, Morro do Trobudo (1.306m), Portal de acesso ao Morro da Boa Vista e Costão do Frade

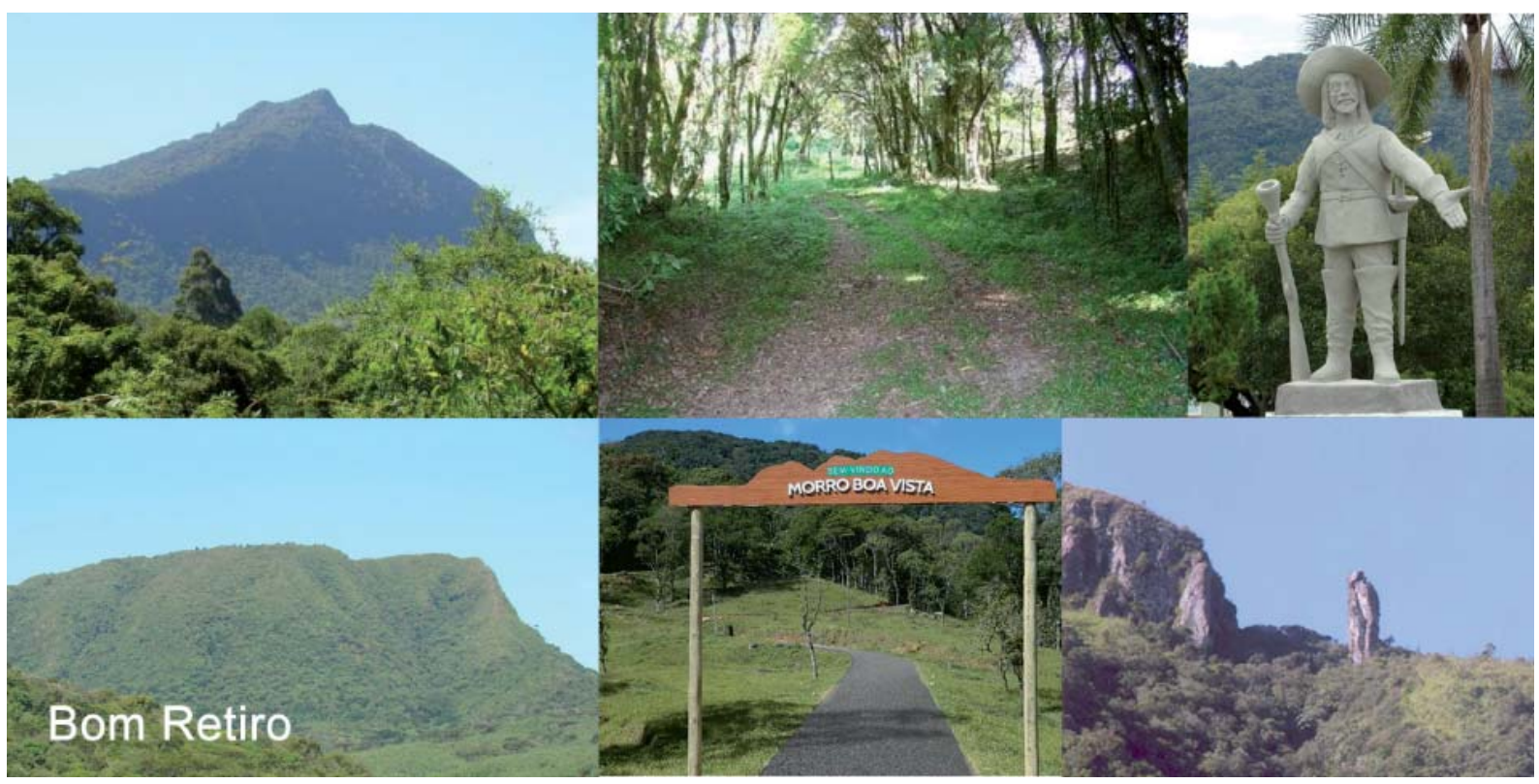

Fonte: Elaborada pelos autores.

Os campos da Boa Vista e de Bom Retiro se estendiam pelo planalto num território que foi denominado por "Paraiso do Sertão" (BRÜGGEMANN, 2008; WERNER, 2004), atuais municípios de Alfredo Wagner, Bom Retiro e Bocaina do Sul. Ali encontravam afluentes do Rio Uruguai e Rio Canoas, chegando à Vila de Lages, atual município de Lages.

Paraíso do Sertão, foi a expressão que ocorreu ao Alferes, depois vencer com muito esforço e sacrifícios os trechos fortemente erodidos e recobertos de vegetação das encostas da Serra Geral. A partir daí, chegou, finalmente aos campos que, a partir do Morro do Trombudo, se estendem para oeste. (COELHO, 1856, p. 27).

A Vila de Lages foi fundada em 1766, sendo um local estratégico para as rotas mercantilistas do planalto paulista, no caminho São Paulo-Viamão, aberto em 1727. Todavia o sertão separava Lages do então litoral da Capitania de Santa Catarina, onde freguesias foram se formando desde 1500, a saber, São Francisco do Sul, Desterro, Laguna, entre outras. Nesse sentido, a abertura do Caminho das Tropas Desterro-Lages se configurou num novo período mercantil e administrativo, haja vista que a vila de Lages posteriormente foi incorporada ao território catarinense (BRÜGGEMANN, 2013).

Igualmente a São José, Lages também se beneficiou do Caminho das Tropas, transformando-se em importante polo comercial, industrial e turístico de Santa Catarina, e o legado deixado pelos tropeiros é bem presente na cidade. Um exemplo é a Fazenda Cajuru, tombada como patrimônio cultural estadual (P.T. n. 294/2005), construída junto ao antigo trajeto, em 1865. Outro exemplo é a Coxilha Rica, que concentra o maior e mais importante acervo de bens culturais relacionado ao ciclo do tropeirismo (SANTOS, 2015). Composto por casarões, corredores e mangueirões de taipas de pedras, cemitérios, entre outros, trata-se do único bem patrimonial do Caminho das Tropas que o Instituto do Patrimônio Histórico e Artístico Nacional (IPHAN) tem mapeado, por meio do Inventário Nacional de Registro Cultural (INRC), auxiliando na identificação e proteção do 
patrimônio cultural relacionado aos Caminhos das Tropas. O Monumento Os Tropeiros também é um importante atrativo turístico, em se tratando de referências históricas e culturais sobre a abertura do caminho Desterro-Lages.

Lages também é reconhecida como a "Capital Nacional do Turismo Rural", haja vista o pioneirismo nessa segmentação de turismo, iniciado na década de 1980, quando fazendas centenárias da região começaram a adaptar-se para receber visitantes.

O Turismo Rural, além do comprometimento com as atividades agropecuárias, caracteriza-se pela valorização do patrimônio cultural e natural como elementos da oferta turística no meio rural. Assim, os empreendedores, na definição de seus produtos de Turismo Rural, devem contemplar com a maior autenticidade possível os fatores culturais, por meio do resgate das manifestações e práticas regionais (como o folclore, os trabalhos manuais, os "causos", a gastronomia), e primar pela conservação do ambiente natural. (BRASIL, 2006, p. 19, grifos do autor).

Figura 8 - Atrativos turísticos do município de Lages: Coxilha Rica, Fazenda Cajuru. Monumento os Tropeiros, Taipa de Pedra e vista da cidade.

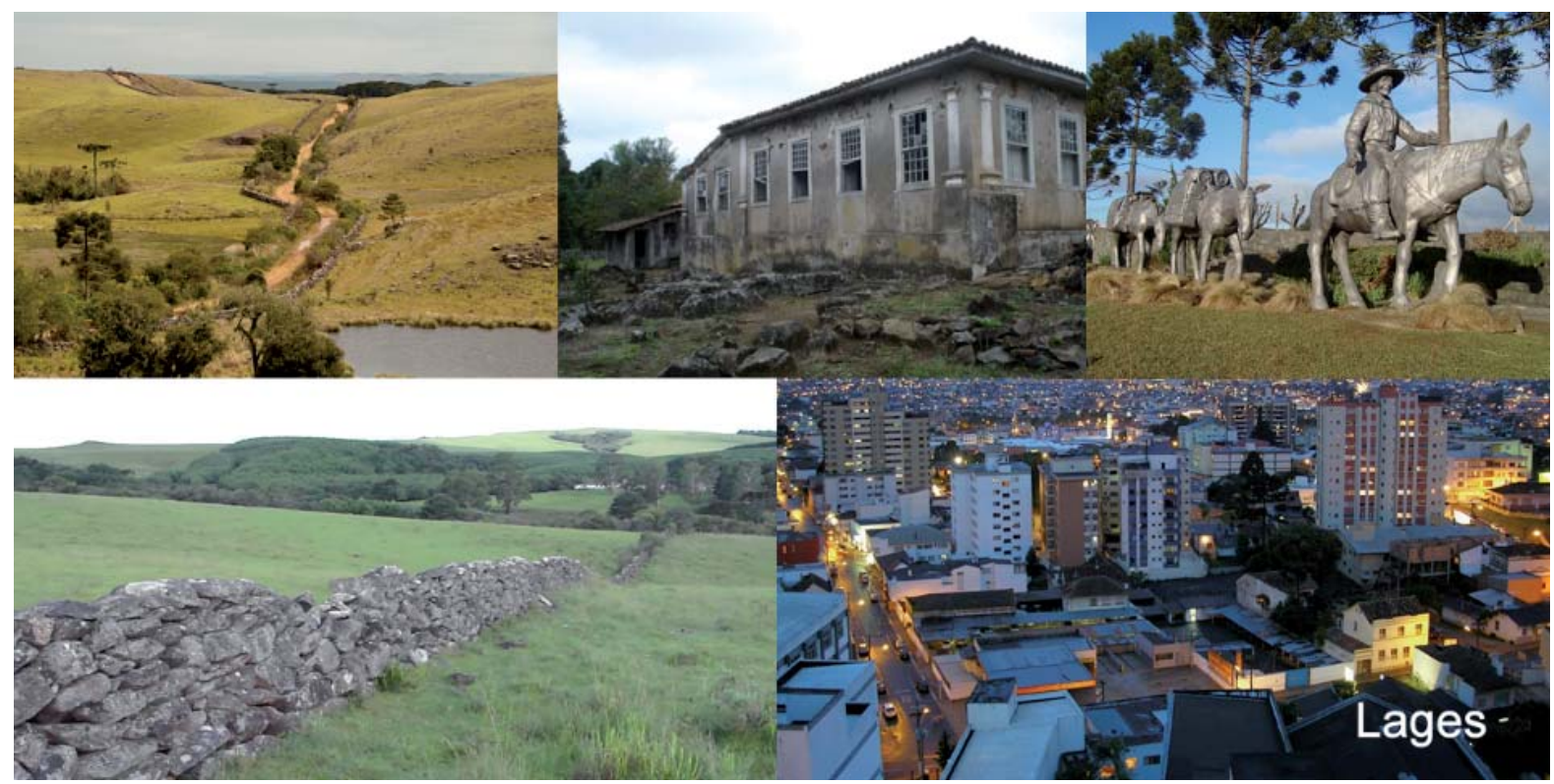

Fonte: Elaborada pelos autores.

Toda viagem turística é uma experiência cultural, mas nem todo turista é um turista cultural. O que define o Turismo Cultural é a motivação da viagem em torno de temas da cultura (BRASIL, 2010). Nesse sentido, pensar num turismo cultural para o Caminho das Tropas poderá, de certa maneira, contribuir para a própria memória do lugar, visto que todos nós nos tornamos ligados a edificações e locais que criam beleza, marcam eventos de significado histórico e cultural e servem como um locus para encontro da comunidade e identidade de uma cidade, onde o meio ambiente natural e construído se articula em ricas camadas de história, memória e narrativas (BAUER, 2015b).

Assim, o Caminho das Tropas Desterro-Lages torna-se uma marca, um elo, entre o presente e o passado das cidades por onde ele passou, formando comunidades distintas, mas que carregam características culturais que se assemelham, servindo como um espelho a todos; ou seja, 
o Caminho das Tropas passa a ser um fator de identidade e pertencimento comum, partilhado por todos.

O patrimônio cultural passa a ser a própria cultura do local, sustentando sua história, causando um fator de identificação de todos com o local. Não obstante, ao propor um turismo cultural para um determinado lugar, todos devem ter clareza daquilo que desejam mostrar, pois, como dito, o desejo de se desenvolver um turismo ligado à cultura deve emanar da própria população local, à medida em que essa se sinta sensibilizada e valorize seu próprio legado.

Em se tratando de políticas públicas para o desenvolvimento de um turismo cultural para o Caminho das Tropas, podemos notar algumas ações pontuais nos municípios que integram a rota original. O município de São José possui bens culturais tombados em nível municipal e estadual, contudo estes têm mais identificação com a fundação da freguesia de São José da Terra Firme e com os seus colonizadores açorianos. Uma exceção seria o Píer do Rio Maruim (tombado pelo Decreto n. 18.703/2005), visto que, originalmente se tratava de uma benfeitoria do governo para o antigo Caminho das Tropas.

São Pedro de Alcântara, primeira colônia alemã de Santa Catarina, tem se planejado turisticamente enquanto cidade de cultura germânica. Entretanto o município, emancipado de São José em 1994, possui dois atrativos turísticos identificados para um potencial turismo cultural sobre a presença dos tropeiros na região. Trata-se da Pedra das Letras e do Caminho do Salto, este já tombado pela municipalidade como patrimônio histórico e cultural (Lei n. 297/2004).

Angelina foi a cidade que mais sofreu com o isolamento geográfico após novas rotas para o Caminho das Tropas terem sido abertas. Também, esta pesquisa não conseguiu levantar indícios de atrativos turísticos na cidade para o desenvolvimento de um turismo cultural sobre esta temática. Apenas a literatura historiográfica catarinense registra algumas descrições sobre a inclusão da cidade na rota originalmente traçada, nos relatos do próprio alferes Antônio José da Costa. Observa-se que a própria história local se encontra desfocada, uma vez que poucos conhecem a origem e a fundação da cidade, ocorrida por meio da implantação da Colônia Nacional, em 1860.

Igualmente a São Pedro de Alcântara e Angelina, o município de Rancho Queimado também tem divulgado a cultura germânica com maior ênfase, apesar do próprio nome da cidade estar ligado ao universo dos tropeiros. Suas atuais localidades foram criadas a partir das linhas de colonização da segunda colônia alemã de Santa Catarina, Santa Isabel, em 1847. Destaque para Taquaras, que foi a última linha colonial e está fortemente ligada ao antigo Caminho das Tropas, sendo citada em vasta literatura histórica, além de constar como local estratégico, de intersecção entre todas as rotas e onde os tropeiros pernoitavam. Rancho Queimado possui alguns trechos do caminho original, mas nenhuma iniciativa para o seu tombamento foi evidenciada até o momento. Em 1993, a cidade construiu o Monumento ao Tropeiro, transformando-se em um atrativo turístico local.

As cidades de Alfredo Wagner, Bom Retiro e Bocaina do Sul também foram diagnosticadas com subsídios para o desenvolvimento de um turismo cultural sobre o Caminho das Tropas, todavia esta pesquisa identificou a existência de uma sobreposição de outras culturas. Também a falta de (re)conhecimento com a história do antigo caminho entre o litoral e o planalto paulista permanece distante do dia a dia desses municípios. Alfredo Wagner integra o Vale Europeu, política de regionalização do turismo proposta pelo estado de Santa Catarina; Bom Retiro, considerada a cidade 'portal da serra catarinense', tem promovido o turismo ecológico e de aventura; e Bocaina do Sul permanece isolada, haja vista que se configurava como o "sertão desconhecido" dos campos de Lages. 
Por último, Lages é a cidade que cresceu economicamente no planalto catarinense, uma vez que, dada a importância comercial dos caminhos das tropas, a cidade era um ponto estratégico entre os trajetos Desterro-Lages, São Paulo-Viamão e Lages-Laguna. Nesse sentido, o município possui características culturais que a distingue das demais, identificando-se com a cultura dos tropeiros, dos paulistas e, também, com os gaúchos, todas diretamente ligadas aos antigos caminhos de tropas. Lages possui o maior e mais importante acervo de bens culturais relacionado ao ciclo do tropeirismo, a Coxilha Rica e que poderá ser utilizada como importante atrativo turístico para o desenvolvimento de um turismo cultural, junto com a Fazenda Cajuru, esta já tombada em nível estadual (P.T. n. 294/2005).

\section{CONSIDERAÇÕES FINAIS}

A partir dessa identificação e do mapeamento desses atrativos turísticos patrimoniais, tem-se uma dimensão para se pensar e planejar o desenvolvimento do seu turismo cultural.

O objetivo geral desta pesquisa foi alcançado por meio de etapas específicas, primeiramente fez-se o referencial teórico que suportou os aspectos conceituais e metodológicos da pesquisa, em seguida contextualizou-se histórica e geograficamente aquela região; também são evidenciados os potenciais elementos que poderiam compor um roteiro turístico, abrangendo seus principais atrativos patrimoniais e culturais, além de suas paisagens, destacando a originalidade e sua identidade com a região. Por último, apontam-se algumas considerações para o desenvolvimento turístico do Caminho das Tropas Desterro-Lages, motivadas pela inexistência do seu planejamento turístico até o momento.

Pensar no desenvolvimento de um turismo sobre o Caminho das Tropas Desterro-Lages seria, antes de tudo, passar a entender esse território de cidades com culturas distintas, enquanto uma região com características similares. Ou seja, um espaço vivido e sentido pelos seus habitantes (FRÉMONT, 1980). Diante do exposto, as questões regionais assumem importância cada vez maior para o turismo e estimulariam o desenvolvimento de uma infraestrutura turística, além de outras atividades econômicas para o Caminho das Tropas, a saber, o desenvolvimento do comércio, dos transportes, dos meios de hospedagem, das agências de viagem e do artesanato regional.

A presente pesquisa evidenciou alguns patrimônios culturais da primeira rota mercantilista entre o litoral catarinense e o planalto, num território compreendido por nove municípios. Os vestígios históricos e manifestações culturais aqui apresentados podem ser considerados como atrativos turísticos para o desenvolvimento de um turismo cultural sob a perspectiva da presença dos tropeiros nessa região. Alguns desses atrativos já são ofertados turisticamente e poderiam ser mais bem planejados, em se tratando de uma promoção estratégica, com foco no desenvolvimento local. As políticas públicas existentes dizem respeito ao processo de tombamento de patrimônios de referência cultural tropeira, devido a sua relevância histórica e cultural. Finalmente, o turismo cultural para o Caminho das Tropas seria uma forma de manter a dinâmica da vida da região, compreendendo e reinterpretando essas paisagens culturais.

Por fim, acredita-se que esta pesquisa possa contribuir com o planejamento do turismo de regiões que têm como foco o turismo cultural. Por meio de um diagnóstico histórico e de um levantamento de potencialidades de atrativos turísticos, tem-se a possibilidade de planejar, estrategicamente, ações para o desenvolvimento turístico, social e econômico de um lugar. 


\section{REFERÊNCIAS}

ANTONINI, Bianca Oliveira. A gastronomia típica da ilha de Santa Catarina: um elemento de importância para o turismo cultural. 2003. Tese (Doutorado em Turismo e Hotelaria)- Universidade do Vale do Itajaí (UNIVALI), Itajaí, 2003.

BARRETTO, Margarita. Manual de iniciação ao estudo do turismo. 17. ed. Campinas, SP: Papirus, 2006.

BAUER, Jonei. E. Sertão desconhecido: de Desterro a Lages. Portal do Rancho, 2015a. Disponível em: <http:// www. portaldorancho.com.br/portal/sertao-desconhecido-de-desterro-a-lages>. Acesso em: 12 dez. 2016.

. A memória e a memória do lugar. Portal do Rancho, 2015b. Disponível em: <http://www. portaldorancho.com.br/portal/trinta_anos_museu>. Acesso em: 18 dez. 2016.

Tropeirismo, patrimônio da humanidade. Portal do Rancho, 2012. Disponível em: <http://www. portaldorancho.com.br/portal/tropeirismo-patrimonio-da-humanidade>. Acesso em: 21 nov. 2016.

Gruta de Angelina: a Virgem Maria que em três sonhos indicou o local. Portal do Rancho, 2011. Disponível em: <http://www.portaldorancho.com.br/portal/gruta-de-angelina-a-virgem-maria-que-emtres-sonhos-indicou-o-local>. Acesso em: 20 dez. 2016.

BECKER, Bertha K. Políticas e planejamento do turismo no Brasil. Caderno Virtual de Turismo, São Paulo, v. 1, n. 1, p. 1-7, 2001.

BENI, Mário C. Análise estrutural do turismo. São Paulo: SENAC, 2001.

BRASIL. Ministério do Turismo. Turismo cultural: orientações básicas. 3. ed. Brasília: Ministério do Turismo, 2010.

Ministério do Turismo. Segmentação do turismo: marcos conceituais. Brasília: Ministério do Turismo, 2006.

BRÜGGEMANN, Adelson André. A sentinela isolada: o cotidiano da colônia militar de Santa Tereza (184-1883). 2013. Dissertação (Mestrado em História) - Universidade Federal de Santa Catarina (UFSC), Florianópolis, 2013.

Soldados (in)visíveis: componentes do Exército brasileiro na colônia militar de Santa Thereza (1854-1883), província de Santa Catarina. In: SIMPÓSIO NACIONAL DE HISTÓRIA - ANPUH, 26. Anais... São Paulo, julho 2011.

Ao poente da Serra Geral. Florianópolis: UFSC, 2008.

BRUM, Nilo Bairros de. Caminhos do sul. Porto Alegre: Metrópole, 1999.

CAMARGO, Haroldo L. Patrimônio histórico e cultural. São Paulo: Aleph, 2002.

CARVALHO, Paulo; FERNANDES, João Luís. Patrimônio cultural e paisagístico: políticas intervenções e representações. Coimbra, Portugal: Universidade de Coimbra, 2012

CHOAY, Françoise. A alegoria do patrimônio. São Paulo: Estação Liberdade/Unesp, 2001.

COELHO, Manoel J. Memória histórica da Província de Santa Catarina. Desterro: Desterrense, 1856. Disponível em: <http://fortalezas.org/midias/arquivos/1309.pdf>. Acesso em: 22 jun. 2018.

CORIOLANO, Luzia N. M. Lazer e turismo para o desenvolvimento na escala humana. Revista Lusófona de Estudos Culturais, Aveiro, Portugal, v. 1, n. 2, p. 126-41, 2013.

A contribuição do turismo ao desenvolvimento local. In: PORTUGUEZ, Anderson P.; SEABRA, Giovanni; QUEIROZ, Odaléia T. M. M. (Org.). Turismo, espaço e estratégias de desenvolvimento local. João Pessoa, PB: Editora Universitária da UFPB, 2012. p. 61-70.

COSTA, Carlos. Turismo e cultura: avaliação das teorias e práticas culturais do sector do turismo. Análise Social, Lisboa, Portugal, v. XL, n. 175, p. 279-95, jul. 2005.

FRÉMONT, Armand. A região, espaço vivido. Coimbra: Almedina, 1980. 
FUNDAÇÃO CATARINENSE DE CULTURA. Decreto n. 5.979, de 5 de dezembro de 2002. Conjunto de Edificações - Vila Kretzer - Santa Filomena (comunidade), SC 407. Disponível em: <http://www.cultura. sc.gov.br/1409-patrimonio-cultural/bens-tombados/4383-4383-sao-pedro-de-alcantara>. Acesso em: 22 jun. 2018.

GIL, Antonio C.; OLIVA, Eduardo C.; SILVA, Edson C. Turismo e regionalidade. Revista Turismo Visão e Ação, Itajaí, SC, v. 11, n. 1, p. 92-111, jan./abr. 2009.

HAMMERL, Priscyla C.; SILVEIRA, Rogério L. L. Por um desenvolvimento turístico: o planejamento de Campos de Jordão em uma escala local/regional/global (1950-1960). TURyDES- Revista de Investigación em Turysmo y Desarrollo Local, Málaga, Espanha, v.. 6, n. 15, dez. 2013.

HENRIQUES, Cláudia. Turismo, cidade e cultura: planeamento e gestão sustentável. Lisboa: Sílabo, 2003.

INSTITUTO BRASILEIRO DE GEOGRAFIA E ESTATÍSTICAS (IBGE). Censo demográfico, 2010. Disponível em: <https://censo2010.ibge.gov.br/resultados.html>. Acesso em: 22 jun. 2018.

JOCHEM, Toni V. A epopeia de uma imigração: resgate histórico da imigração. Águas Mornas, SC: Edição do Autor, 1997.

. Pouso dos imigrantes. Florianópolis: Papa-livro, 1992.

JULIÃO, Liliana C. S. Cidade, cultura e turismo: o impacto turístico em Guimarães, capital europeia da cultura. 2012. 113p. Dissertação (Mestrado em Turismo) - Escola Superior de Hotelaria e Turismo do Estoril, Portugal, 2012.

LAGE, Beatriz H. G.; MILONE, Paulo C. Turismo: teoria e prática. São Paulo: Atlas, 2000.

LE BOURLEGAT, Cleonice A. Ordem local como força interna de desenvolvimento. Interações - Revista Internacional de Desenvolvimento Local, Campo Grande, MS, v. 1, n. 1, p. 13-20, set. 2000.

LUZ, Aujor A. Os fanáticos: crimes e aberrações da religiosidade dos nossos caboclos. Florianópolis: Imprensa Oficial, 1952.

MARTINS, Sérgio Ricardo Oliveira. Desenvolvimento local: questões conceituais e metodológicas. Interações, Campo Grande, MS, v. 3, n. 5, p. 51-9, set. 2016.

MOLETTA, Vânia F. Turismo cultural. Porto Alegre: SEBRAE/RS, 1998.

OLIVEIRA, Antônio P. Turismo e desenvolvimento: planejamento e organização. 5. ed. rev. e ampl. São Paulo: Atlas, 2005.

OLIVEIRA, Gilson B.; LIMA, José Edmílson S. Elementos endógenos do desenvolvimento regional: considerações sobre o papel da sociedade local no processo de desenvolvimento. Revista FAE, Curitiba, v. 6, n. 2, p. 29-37, maio/dez. 2003.

ORGANIZAÇÃO MUNDIAL DO TURISMO (OMT). Introducción al turismo. Madrid: [s.n.], 1998.

PIAZZA, Walter F. Atlas histórico de Santa Catarina. Florianópolis: Secretaria de Educação do Estado de Santa Catarina, 1971.

PINTO-CORREIA, Teresa. Sobre o abandono rural em Portugal - potenciais das amenidades das paisagens rurais no NE Alentejano. 2011. Disponível em: <http://dspace.uevora.pt/rdpc/bitstream/10174/3599/1/ Apresenta\%C3\%A7\%C3\%A3o_Pinto\%20Correia_Idanha\%202011.pdf>. Acesso em: 21 nov. 2016.

PINTO-CORREIA, Teresa.; CANCELA, d'Abreu Augusto; OLIVEIRA, Rosário. Identificação de unidades de paisagem: metodologia aplicada a Portugal Continental. Finisterra - Revista Portuguesa de Geografia, v. 36, n. 72, p. 195-206, 2001.

RICHARDS, Greg. Cultural tourism - global and local perspectives. New York: The Haworth Hospitality Press, 2008

RUSCHMANN, Doris V. M. Turismo e planejamento sustentável: a proteção do meio ambiente. Campinas, SP: Papirus, 1997. (Coleção Turismo). 
SANTOS, Fabiano Teixeira dos. A Casa do Planalto Catarinense: arquitetura rural e urbana nos Campos de Lages, séculos XVIII e XIX. Lages, SC: Super Nova, 2015.

SANTOS, Milton. Técnica, espaço, tempo: globalização e meio técnico-científico informacional. São Paulo: Editora da Universidade de São Paulo, 2008.

. A natureza do espaço. São Paulo: Hucitec, 1996. v. 1.

. Espaço e método. São Paulo: Nobel, 1985.

SANTOS, Roselys I. C.; ANTONINI, Bianca O. La gastronomia típica de la Isla de Santa Catarina - Brasil. Su identidad como atrativo para el turismo cultura. Estudios y Perspectivas en Turismo, Buenos Aires, Argentina, v. 13, n. 1-2, 2004.

SÃO JOSÉ (Município). Decreto n. 18.699/2005. Decreto de Tombamento Casario construído no século XIX e início do XX. Disponível em: <http://www.saojose.sc.gov.br/images/uploads/geral/Decretos_de_ tombamento_dos_bens_hist\%C3\%B3ricos_do_munic\%C3\%ADpio.pdf>. Acesso em: 22 jun. 2018.

. Decreto n. 18.703/2005. Decreto de Tombamento Pier do Rio Maruim. 2005b. Disponível em: <http://www.saojose.sc.gov.br/index.php/turista/pontos-turisticos/P12>. Acesso em: 22 jun. 2018.

SÃO PEDRO DE ALCÂNTARA (Município). Lei Ordinária n. 297/2004. Tomba os Bens que Menciona e dá outras providências. Disponível em: <http://static.fecam.net.br/uploads/11/arquivos/14488_LEl_N29704. pdf>. Acesso em: 22 jun. 2018.

. Lei Ordinária n. 011/1999. Declara Vila Kretzer Patrimônio Histórico de São Pedro da Alcântara. Disponível em: <http://static.fecam.net.br/uploads/11/arquivos/14488_LEl_N01199.pdf>. Acesso em: 22 jun. 2018.

SCHLÜTER, Regina G.; NORRILD, Juana A. Turismo y patrimonio en el siglo XXI. Buenos Aires, Argentina: Centro de Investigaciones y Estudios Turísticos, 2002.

UNWTO. Tourism and Intangible Cultural Heritage. 1. ed. Madrid: UNWTO, 2012.

VIANNA, Silvio L. G.; HOFFMANN, Valmir E. Classificação dos municípios catarinenses com base nos indicadores para a formação de um cluster de turismo cultural. Caderno Virtual de Turismo, Rio de Janeiro, v. 9, n. 2, p. 1-16, 2012.

WERNER, Antônio C. Caminhos da Integração Catarinense: do caminho das Tropas à rodovia BR 282. Florianópolis: Edição do autor, 2004.

WORLD TOURISM ORGANIZATION (WTO). Tourism and intangible cultural heritage, 1. ed. Madrid: UNWTO, 2012. Disponível em: <https://www.immaterieelerfgoed.nl/nl/media/inline/2017/9/14/tourism_and_ intangible_cultural_heritage_unwto.pdf>. Acesso em: 22 jun. 2017.

\section{Sobre os autores:}

Jonei Bauer: Mestrando do Programa de Pós-graduação Mestrado Acadêmico em Turismo e Hotelaria (UNIVALI). Licenciado em Letras (UNISUL) e bacharel em Museologia (UFSC). E-mail: prof.jonei@yahoo.com.br

Ana Paula Lisboa Sohn: Mestre em Relações Internacionais (UNISUL). Doutora em Engenharia de Produção (UFSC). Bacharel em Administração (UFSC) e Pedagogia (UDESC). Docente do Programa de Pós-Graduação em Turismo e Hotelaria da Universidade do Vale do Itajaí (UNIVALI). E-mail: anasohn@hotmail.com 
